\title{
Parenting And Self Esteem Levels Of Children
}

\author{
Noerma Rosalina, Najlatun Naqiyah \\ Universitas Negeri Surabaya \\ Surabaya, Indonesia \\ noerma.170713250003@mhs.unesa.ac.id
}

\begin{abstract}
The purpose of this research is to see parenting and level of self-esteem. This research using descriptive analytic methods in junior high school, with a cross-sectional approach The Self Esteem scale and parenting were given to 60 students. The univariate analysis showed that 51 students $(85 \%)$ with authoritarian parenting with low self-esteem. There are three things that affect the level of children's self-esteem, namely: age, gender, and parenting patterns. Parenting is very important because it is through the parenting process that the child grows and develops into an individual figure with a set of characteristics in line with what he received during the upbringing process. There is a need for follow-up on parenting to produce a high level of self-esteem in a child. The
\end{abstract}

\section{Keywords - Self Esteem; Parenting}

\section{INTRODUCTION}

The family is a place to practice for children to know their first life, to know reality, and to learn the best way to deal with everything. Therefore, the family plays an important role in providing adequate and realistic conditions about everything that a child faces when he has to leave the family, and interact with the wider environment.

Parents must understand how to treat and educate children effectively, will succeed to help her child overcome difficult times in her life. Parents understand the importance of preparing children for success. He also understands that success can be achieved if you have a high level of Self Esteem early on. Because will help to adapt well in adulthood. It will be a tough task for parents, especially a mother when self is a parent whose development has a low level of selfesteem.

Childcare is an indication that occurs between parenting with children who are cared for. Parenting is an effort that is directed to change the behavior in accordance with the desire of the caregiver [1]. Parenting is very important because it is through the nurturing process that the child grows and develops into an individual figure with a set of characteristics in line with what he received during the upbringing process [2].

Child care patterns also affect the level of self-esteem in the future. Self-esteem is a person's that develops from the feeling of belonging, feeling competent (feeling efficient, productive) and feeling worthwhile [3]. Self Esteem begins to appear clearly when the child enters the age of 2 years and develops with age. Self-esteem who appeared at the time was a feeling of pride that he had succeeded in doing something on his own. There is a desire to make something, to investigate and to satisfy his curiosity, to manipulate and to change the environment. The impulse for this exploration is so strong in self-control. If the parents hinder these needs, the self-esteem level becomes low.

Research conducted by Robins, Trzesnieski, Gosling, and Potter (2012) shows that the age of children (9-12 years old) has the highest level of self-esteem than any other age; then decreased sharply from childhood to adolescence (13-17 years) and continued to decline in student age (18-22 years); then increased in the post-student age (23-29 years) until the age of 30-40 years. The increase continues until the age of 4050 years, ultimately self-esteem decreased conspicuously from the age of 60-80 years. Changes in self-esteem that occurs because at each level of age have different tasks that will affect the level of individual self-esteem.

Facts on the ground, many parents apply various parenting patterns to their children. According to Papilia \& Olds (1993), there are some characteristics of parents who can improve or decrease the child's Self Esteem. According to them, warm, responsive and realistic parents will increase the child's Self Esteem, while perfectionist, criticizing, over-controlling or overprotecting, indulgent, ignorant, and non- clear and consistent rules will decrease the child's Self Esteem level [4].

From the description above, the researchers are interested in discussing the parenting pattern of parents to increase the self-esteem of children. Children need to be accompanied, educated and get proper care for self-esteem can be positive and improved the quality of life of the child.

\section{METHOD}

\section{A. Self Esteem}

Self-esteem is one of the disciplines studied to know how the concept of self is actual. Experts give an explanation of what self-esteem is and what factors influence it. Coppersmith (1967) states that a self-esteem is a form of self-evaluation of a person to himself, as well as maintaining the assumption or self-assessment. Self-esteem can be expressed through the acceptance or rejection of the evaluation. The object of evaluation or self-assessment is usually related to the competence or potential of the individual, the success or failure of the individual. In addition, the object of an individual's evaluation is whether he or she is acceptable to the environment and accepts oneself for what they are [5]. 
Owens (1994) defines self-esteem based on Rosenberg (1965) self-esteem is an attitude that has two components on the assessment of the object (self) that is a positive component and or negative component. A positive component called selfworth is also a level of judgment that the individual's self-has a worthy moral or virtue. The negative component is called self-depreciation in the form of self-criticism. This often happens when individuals underestimate the feelings, abilities, potential, and goodness that exist in the individual [6].

Tafordi and Swann (1995) explain that self-esteem is influenced by the social environment of individuals, the place where individuals live and interact with others. Like Owens (1994), Tafarodi and Swann (1995) also distinguish selfesteem into two components, namely self-liking and selfcompetence [7].

Self-liking is an effective judgment of self, whether it is accepted or rejected, approved or denounced by the internalized value of social in the individual. Self-competence is an assessment that self is capable, has potential, effective and can be controlled and reliable. Self-competence is the result of the success of manipulating the physical or social environment associated with the realization and achievement of goals

According to Baron, Branscombe, and Bryne (2008), selfesteem is the level of self-acceptance positively or negatively to all attitudes of self. Self-esteem is very responsive to the events experienced by individuals in everyday life, for example when an individual is able to achieve the desired goal then self-esteem increases, but if the failure then self-esteem will be low[8].

Nathaniel Brandon [9] defines a good or positive selfesteem as "the feeling good" and "the doing well". It is a feeling of confidence that the child has the right to be happy, to feel useful, to feel comfortable expressing desires and needs, entitled to enjoy the results of his business and to have the ability to think and overcome the problems encountered in his life

\section{B. Factors Affecting Self Esteem}

High or low self-esteem formed due to the interaction between individuals with the social environment, so the development of self-esteem will be influenced by several factors. Some factors that affect the level of self-esteem are as follows:

\section{- Age}

Research conducted by Robins, Trzesnieski, Gosling, and Potter (2012) shows that the age of children (9-12 years old) has the highest level of self-esteem than any other age; then decreased sharply from childhood to adolescence (13-17 years) and continued decline in student age (18-22 years); then increased in the poststudent age (23-29 years) until the age of 30-40 years. The increase continues until the age of 40-50 years, ultimately self-esteem decreased conspicuously from the age of 60-80 years. Changes in self-esteem that occurs because at each level of age have different tasks that will affect the level of individual self-esteem.

\section{- Gender}

Robins, Trrzesniewski, Gosling, and Potter (2002) suggest that there is a difference in the level of selfesteem, men higher than women. Differences in the level of self-esteem between males and females occur only during adolescence and continue into old age.

\section{- $\quad$ Parenting}

Loeb, Horst, and Horton (2000) research show that parenting with the use of commanding behavior is generally associated with low self-esteem in children. Other studies of the care of Martinez, Gracia, and Yuberco (2007) suggest that parenting styles using violence and punish behavior (Bush, Peterson, Cobas \& Sipple, 2002) by parents cannot improve the child's self-esteem. Self-esteem is better developed in family environments that emphasize giving suggestions and help and possible choices in children.

\section{Parenting}

Parenting is a behavioral pattern defined in children and is relatively consistent over time. This pattern of behavior can be felt by the child, in terms of negative or positive. According to Baumrind (1967), there are three kinds of parenting patterns:

\section{- Democratic parenting}

Democratic parenting is a parenting pattern that prioritizes the interests of the child but does not hesitate to control them. Parents with this parenting are rational, always underlying their actions on rationality or thoughts. Parents of this type are also reluctant to the child's ability. Parents of this type also give the child the freedom to choose and perform an action, and his approach to the child is warm.

\section{- Authoritarian parenting}

Authoritarian upbringing, on the other hand, tends to set an absolute standard to be followed, usually accompanied by threats. For example, if you do not want to eat, then do not buy toys. Parents of this type also tend to force, rule, punish. If the child does not want to do what is said by parents, then parents with this type do not hesitate to punish the child. Parents with authoritarian parenting also do not recognize compromise, and in communications are usually oneway, does not require feedback from their children to understand what their children really want.

\section{- $\quad$ Permissive parenting}

Permissive parenting patterns or can be called as well as the grooming of this shopper usually provides very loose supervision. Giving the child an opportunity to do something without enough 
supervision from him/her. They tend not to reprimand or raise children when children are in danger, and very little guidance is given by them. However, this type of parent is usually warm, so it is often liked by children.

\section{The Role of Parents in Enhancing the Self Esteem of Children}

A poorly developed or negative self-esteem can result in a person low to achieve, falling into the use of illegal drugs, lacking independence, demonstrating criminal behavior and other moral behavior. Self-esteem is also a global evaluative dimension of self that refers to "selfworth" or "self-image". Children can sense that he is open to a human being, but also a good human. Of course, not all children have an entirely positive image. Children can make self-evaluation in many areas of their lives such as academia, sports, appearance, friendship, social acceptance, and so on.

There are several attributes of parents who are often associated with high self esteem of children (Santrock, 1995), namely the ability to express affection, concern for children's problems; harmony within the family; participation in family activities; readiness to provide competent and organized assistance to children when they need it; the application of clear and fair rules; adherence to the rule; and the granting of freedom to children within clearly identified limits.

According to Harlock (1978) basically, the relationship between parents and children depends on the attitude of parents. If the attitudes of parents are positive, the relationship between parent and child will be much better. Many cases of poor adaptation in adults are based on the parents' and children's early unfavorable relationships, as parents lack positive self-esteem. Susan Harter (Santrock, 1995) an expert and self-esteem researcher, states that children's self-esteem levels can be enhanced by the following principles:

- Identify the causes of low self-esteem and areas of competence that are important to the child. Selfesteem of children will be high if they have competence in areas that are considered important to him.

- Emotional support and social approval. The main source of emotional support is that the family greatly affects the child's self-esteem. Alternative support in the form of confirmation from other people, teachers, and other significant adults, can also affect the child's self-esteem.

- Improvement of achievement. Teaching real skills in children often improves achievement and thereby improves the child's self-esteem.

- Facing the problem. Self-esteem also often increases when children experience a problem and try to deal with it, open to avoid it. With the opportunity to face problems, then the children will behave and act realistically, honestly, and not defensive. This will result in a more lucrative self-evaluation thinking, which results in self-generated approval, which will enhance self-esteem.

This research uses descriptive analytic with the Crosssectional approach, that is research type which emphasizes at time of measurement or observation of independent variable data and dependent only one time, and no follow up is needed. The population is students of SMP Negeri 32 Surabaya. The sample of research is 60 respondents. Stratified random sampling used is proportionate stratified random sampling that is sampling technique which if population have a member or heterogeneous element and stratified proportional [10].

The tools used are the scale of self-esteem level and parenting patterns of parents in the form of questionnaires. This scale uses "Likert scale", if the respondent "strongly agrees" is given a score of 5 and if "strongly disagree" is given a score of 1 for a favorable statement, and if the respondent answers "very unlikely" given a score of 5 and if " strongly agree "was given a score of 1 for a statement that direction is negative (unfavorable) (Anwar, 2011). Parenting pattern of parents as an independent variable with the self-esteem of children as the dependent variable.

Data analysis consisted of univariate and bivariate analysis with Chi-Square statistic test for knowing the relationship of both variables with $95 \%$ confidence level, H0 refused if $\rho>\alpha$ (0.05).

\section{RESULT AND DISCUSSION}
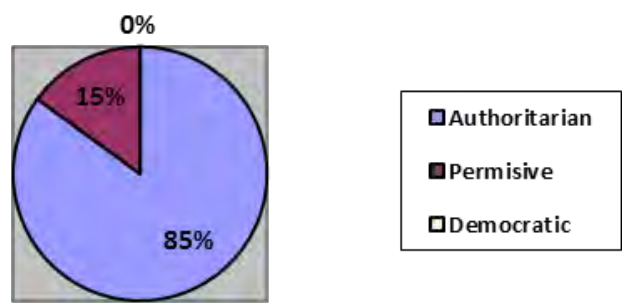

Fig. 1. Parenting patterns in SMP Negeri 32 Surabaya

Figure 1 states that 51 respondents or $85 \%$ in SMP Negeri 32 Surabaya have authoritarian parenting patterns and 9 respondents or $15 \%$ in SMP Negeri 32 Surabaya with parenting pattern and no democratic parenting.

Parenting is a pattern of interaction between parents and children, a way of attitudes or behavior of parents when they interact with children, including how to apply the rules, teach values or norms, give commands and show good attitude and behavior so as a role model for their children [11].

Authoritarian parenting involves a coercive approach, a rule that must be followed by children [12]. Such an approach is usually less responsive to the rights and desires of the child. Communication is done more in one direction and more often in the form of orders, so that the willingness of children less heard, and usually make children tend to stay silent and close themselves [13]. 
Children who are still in junior high level, need direction from parents and are in the early stages of adolescence. Therefore, more parents dominate and control the behavior and emotions of children. Parents with authoritarian parenting are pushy and always require child obedience, in order to behave as desired by their parents [14].

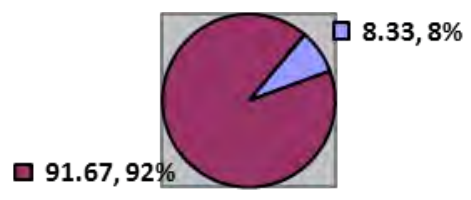

\section{口High
口Low}

Fig. 2. Level of Self Esteem at SMP Negeri 32 Surabaya

Figure 2 states that 55 children or $91.67 \%$ have low selfesteem level and 5 other children or $8.33 \%$ have high selfesteem level.

Coppersmith, 1967 argues that a self-esteem is a form of self-evaluation of a person to himself, as well as maintaining the assumption or self-assessment. Tafordi and Swann (1995) explain that self-esteem is influenced by the social environment of individuals, the place where individuals live and interact with others [5].

The results show that more students of SMP Negeri 32 Surabaya have low self-esteem level. Behavior that appears there is the child's behavior that looks at the child is embarrassed when trying new things, slowly adapt to peers and depend on friends when there is a school task.

Children will be more satisfied with the results obtained. This is reinforced by research conducted by Robins, Trzesnieski, Gosling, and Potter (2012) shows that the age of children (9-12 years) has the highest level of self-esteem than any other age; then decreased sharply from childhood to adolescence (13-17 years) and continued decline in student age (18-22 years).

Monks (2004) suggests several factors that affect selfesteem are: Family environment, social environment, psychological factors, and gender. The first place of socialization is the family. Fair treatment, providing opportunities for active and democratic education is usually founding in children who have high self-esteem [15].

Parenting style purpose that children can develop potential and manifest his ability, family needs and contribute to the nation and country. Parental personality, attitude and the way of life is the elementary education that will indirectly to the child's personal status grow [16].

A. Parenting Relationships With Self Esteem Child Levels

TABLE 1. PARENTING RELATIONSHIP WITH SELF ESTEEM LEVEL OF CHILDREN IN SMP NEGERI 32 SURABAYA

\begin{tabular}{|c|c|c|c|c|c|c|c|c|}
\hline \multirow{3}{*}{$\begin{array}{l}\text { Level of } \\
\text { Self } \\
\text { Esteem }\end{array}$} & \multicolumn{6}{|c|}{ Parenting } & \multirow{2}{*}{\multicolumn{2}{|c|}{ Total }} \\
\hline & \multicolumn{2}{|c|}{ Authoritarian } & \multicolumn{2}{|c|}{ Permissive } & \multicolumn{2}{|c|}{ Democratic } & & \\
\hline & $\mathbf{f}$ & $\%$ & $\mathbf{f}$ & $\%$ & $\mathbf{f}$ & $\%$ & f & $\%$ \\
\hline High & 0 & 0 & 5 & 8.33 & 0 & 0 & 5 & 8.33 \\
\hline Low & 51 & 85 & 4 & 6.67 & 0 & 0 & 55 & 91.67 \\
\hline Amount & 51 & 85 & 9 & 15 & 0 & 0 & 60 & 100 \\
\hline \multicolumn{5}{|c|}{ Test results of Fisher's Extract Test } & \multicolumn{4}{|c|}{$\mathrm{P}$ value $=0.025$} \\
\hline
\end{tabular}

The relationship between parenting with child self-esteem level can be seen from Chi-square analysis as in table 1.

Seen from Table 1 there are $8.33 \%$ or 5 children with permissive parenting pattern that has high self-esteem level and not found children with a level of self-esteem in authoritarian and democratic parenting. Table 1 can also be seen from 51 children or $85 \%$ receiving authoritarian parenting that has low self-esteem level and 4 children or $6.67 \%$ with permissive parenting have low self-esteem level and no children with self-esteem level in democratic parenting. Based on Chi-square test results obtained $\rho$ value $=$ 0.025 is smaller than $\alpha=0.05$. Means, there is a relationship between parenting with the level of self-esteem of children in SMP Negeri 32 Surabaya.

The family is the smallest unit of social unity that has a central role in fostering its members. The family has the function of caring for, and training children, taking care of and educating children. Family life is one of the first life experienced by a child in a family of children to know the life situation to find and develop themselves. [17].

A family is a place in the interpersonal relationship between parent and child bringing a process of value transformation related to the child's development. Interpersonal relationships appear in the form of family communication between parents and children. Interpersonal relationships within the family are developed in the interpersonal relationship stage to achieve the purpose of family communication. Factors that cultivate interpersonal relationships in interpersonal communication are trust, supportive and open attitude toward their parents [17].

Self-esteem of children is influenced by many factors. One of them is parenting patterns. A total of 60 children obtained authoritarian parenting $85 \%$ with a low self-esteem level $91.67 \%$ and permissive parenting $6.67 \%$ with high selfesteem level of $8.33 \%$. Chi-square test results obtained $\rho$ value $=0.025$ smaller than $\alpha=0.05$, which means there is a significant relationship between parenting parents with the level of self-esteem child.

Self-esteem of children is influenced by many factors. One of them is parenting patterns. A total of 60 children obtained authoritarian parenting $85 \%$ with a low self-esteem level $91.67 \%$ and permissive parenting $6.67 \%$ with high selfesteem level of $8.33 \%$. Chi-square test results obtained $\rho$ value $=0.025$ smaller than $\alpha=0.05$, which means there is a significant relationship between parenting parents with the level of self-esteem child. 


\section{CONCLUSION}

The results of this study concluded that parenting applied by parents in SMP Negeri 32 Surabaya tend to authoritarian, level of self-esteem child in SMP Negeri 32 Surabaya low, and There is a significant relationship of parenting parents with child self-esteem level in SMP Negeri 32 Surabaya.

Parents must understand the parenting pattern given to her child. Parenting patterns that match the character of the child, will make the child's self-esteem level becomes high because children feel appreciated by both parents. In the world of education, self-esteem is needed for children to survive the future. The success of children in reaching the future, it starts in the family environment.

\section{References}

[1] A. Arumdina, "Pengaruh Kesepian Terhadap Pemilihan Pasangan Hidup Pada Dewasa Awal yang Masih Lajang," J. Psychol. Pendidik. dan Perkemb., vol. 2, no. 03, pp. 160-169, 2013.

[2] D. Baumrind, R. E. Larzelere, and E. B. Owens, "Effects of preschool parents' power assertive patterns and practices on adolescent development," Parenting, vol. 10, no. 3, pp. 157-201, 2010.

[3] D. B. Felker and R. A. Dapra, "Effects of question type and question placement on problem-solving ability from prose material," J. Educ. Psychol., vol. 67, no. 3, pp. 380-384, 1975.

[4] M. Lewis and A. Others, "Deception in Three-Year-Olds," Dev. Psychol., vol. 25, no. 3, pp. 439-443, 1989.

[5] D. Coppersmith, "The Data Encryption Standard (DES) and its strength against attacks," IBM J. Res. Dev., vol. 38, no. 3, pp. 243-250, 1994.

[6] P. Williams, "Discussion of Terry Owens' paper.," Journal of Infant, Child \& Adolescent Psychotherapy, vol. 12, no. 1. pp. 10-16, 2013.

[7] R. W. Tafarodi, "Paradoxical self-esteem and selectivity in the processing of social information," J. Pers. Soc. Psychol., vol. 74, no. 5, pp. 1181-1196, 1998.

[8] B. N. R. Reysen S., "Fanship and Fandom: comparisons between sport and non-sport fans," J. Sports Behav., vol. 33, no. 22, pp. 176-193, 2008.

[9] N. P. von der Embse, B. K. Schultz, and J. D. Draughn, "Readying students to test: The influence of fear and efficacy appeals on anxiety and test performance," Sch. Psychol. Int., vol. 36, no. 6, pp. 620-637, 2015.

[10] Sugiyono, Metode Penelitian Kuantitatif, Kualitatif, dan R\&D. 2009.

[11] Kadek Suhardita, "Efektivitas Penggunaan Teknik Permainan Dalam Bimbingan Kelompok Untuk Meningkatkan Kepercayaan Diri Siswa," Ed. Khusus, no. 1, pp. 127-138, 2011.

[12] M. V Martinez, "Computer-assisted cognitive-behavioral therapy for adolescent depression in primary care clinics in Santiago, Chile (YPSAM): Study protocol for a randomized controlled trial," Trials, 2014. [Online]. Available: http://ovidsp.ovid.com/ovidweb.cgi? $=$ JS\&PAGE=reference $\& D=$ cctr \& $\mathrm{NEWS}=\mathrm{N} \& \mathrm{AN}=\mathrm{CN}-01002970$.

[13] N. M. T. Kurniati, E. L. Worthington, E. Kristi Poerwandari, A. S. Ginanjar, and C. Dwiwardani, "Forgiveness in Javanese collective culture: The relationship between rumination, harmonious value, decisional forgiveness, and emotional forgiveness," Asian J. Soc. Psychol., vol. 20, no. 2, pp. 113-127, 2017.

[14] E. S. dkk. Setianingsih, "Pengembangan Model Bimbingan Kelompok Teknik Pemecahan Masalah Untuk Meningkatkan Keterbukaan Diri Siswa," J. Bimbing. Konseling, vol. 3, no. 2, pp. 76-82, 2014.

[15] M. A. Luke, G. R. Maio, and K. B. Carnelley, "Attachment models of the self and others: Relations with self-esteem, humanity-esteem, and parental treatment," Pers. Relatsh., vol. 11, no. 3, pp. 281-303, 2004.

[16] E. Skinner, S. Johnson, and T. Snyder, "Six Dimensions of Parenting: A Motivational Model," Parenting, vol. 5, no. 2, pp. 175-235, 2005.

[17] N. M. Taganing, "Summary for Policymakers," in Climate Change 2013 - The Physical Science Basis, vol. 53, Intergovernmental Panel on Climate Change, Ed. Cambridge: Cambridge University Press, 2008, pp. $1-30$ 